\title{
Career and Work Readiness of Nutrition and Dietetics Trainees in Nigerian Universities
}

\author{
Leshi, 0.0, ttlesh@gmail.com
}

Ogundero, A.F

Affiliation of Authors: Department of Human Nutrition and Dietetics, University of Ibadan,
Nigeria

\section{ABSTRACT}

Beyond having a good degree, graduates are expected to have relevant skills and attributes required to compete and collaborate in a rapidly changing work environment. In recent times, the employability of Nutrition and Dietetics graduates in Nigeria has been of considerable concern. This study was designed to assess the readiness of trainees in the field of Nutrition and Dietetics from Nigerian Universities for career and work engagements.

This descriptive cross-sectional study was carried out among 109 final-year undergraduate and postgraduate students from twelve universities offering Nutrition and Dietetics programme across Nigeria. Data was collected using a semi-structured online questionnaire. Data obtained were background information on the students, their experiences and challenges in their academic pursuits, willingness and readiness to pursue and engage in Nutrition and Dietetics related jobs, as well as their perception of skills and competences for future career and work engagements. The data were analysed using the IBM SPSS version 20.0.

About $73 \%$ of the respondents were females, mainly between ages 21 and 25 years $(62.4 \%)$ and undergraduates (70\%). Among the undergraduate students, $83.4 \%$ had chosen to study Nutrition and Dietetics as a result of personal interest and choice while the postgraduate trainees indicated acquisition of in-depth knowledge of nutrition (60.6\%) and quest to enhance career profile for competitive advantage in job pursuits $(39.4 \%)$ as the core reasons for their choice for the programme. Nearly all the respondents $(96.3 \%)$ reported having enjoyed their training programs. Only half (50.5\%) perceived themselves to be "very ready" and well-prepared for work and career engagement. The top three areas of interest by trainees in Nutrition and Dietetics were Clinical Nutrition and Diet Therapy (60.6\%), Community and Public Health Nutrition (43.1\%), and Sports Nutrition (11.0\%). Three out of every ten trainees had no specific desired skills and competences. While less than half declared that they had no knowledge of the skills and competences desired by employers of nutrition graduates, two-thirds of the trainees perceived themselves as eligible for their choice of work and career.

This study shows that most Nutrition and Dietetics trainees in Nigerian universities are ready and willing to start a career in the field. However, many lack the knowledge of expected skills and competences needed for career engagement. 


\section{INTRODUCTION}

Nutrition is now at the forefront of the global developmental agenda after being neglected for decades. The emergence of the double burden of undernutrition and overweight globally, especially in most low-income countries, has further justified the need to prioritize nutritionrelated activities and interventions (Tzioumis and Adair, 2014; Popkin et al., 2020). To boost efforts towards the elimination of all forms of malnutrition as well as communicable and noncommunicable diseases, nutrition has now been brought to the core of prevention rather than just targeting disease management, as per the United Nations declaration of 2016-2025 as the Decade of Action on Nutrition (FAO and WHO, 2016).

Despite the priority given to nutrition and several significant achievements recorded on reduction in the burden of malnutrition in most of the world, many low-and middle-income countries, especially in sub-Saharan Africa, record little or no success in their battle against malnutrition (Delisle, 2012). The few achievements made are being hampered by the shortage in the numbers, skills, and geographical coverage of nutrition workers in these countries (Fanzo et al., 2015; Delisle et al., 2017). In addition, activities such as the Scaling Up Nutrition initiatives, aimed at achieving national coverage of essential nutrition interventions, are constrained by the lack of human resources in nutrition in many countries (WHO, 2013). The promotion of adequate diet across age groups and optimum infant and young child feeding practices, as well as proper management of malnutrition and nutrition-related non communicable diseases, are among the tasks and responsibilities requiring professional nutritionists and dieticians.

Nutritionists are also needed to design, implement, and evaluate nutrition programmes, and to interact with governments and policymakers for advocacy (Delisle et al., 2017). The role of nutritionists in the food industries, as well as in civil society, are now being recognized and appreciated. Nutrition professionals are also needed in sufficient numbers to ensure adequate and sustainable training and monitoring of those who deliver nutrition-specific or nutrition-sensitive services to communities (Delisle et al., 2017). Concerns have however been raised on the low levels of engagement of nutrition professionals and specialists in the health sector across Africa (Delisle, 2012). A study on nutrition workforce capacity conducted in West Africa confirms poor engagement of nutritionists due to the severe shortage of qualified and experienced nutrition professionals (Sodjinou et al., 2014). Delisle (2012) further revealed that lack of self-confidence, low status of the profession in the health sector, and low salaries contribute to many nutritional professionals taking up other job opportunities.

The need for competency-based training and capacity strengthening among health professionals has been well established (UN, 2011; Delisle, 2012). According to the report of the Global commission on education of health professionals (Frenk et al., 2010), all health professionals needed to be educated to mobilize knowledge and to engage in critical reasoning as well as ethical conduct. In this way, they will be competent to participate in patient-centred and populationcentred health systems (Delisle, 2012). In many high-income countries, Bachelor-level nutritionists and dieticians perform most of the required nutrition activities at the country and district levels, and their competences are maintained through continuous education (Delisle et al., 2017). According to Delisle (2012), technical knowledge provided at the bachelor's degree level serves as the core requirement for nutrition professionals. This justifies the need for a strong cadre of professional nutritionists well trained in general nutrition practice at the undergraduate level. Bachelor-level nutritionists and dieticians are expected to have well-grounded knowledge and 
understanding of food composition, food systems, food behaviour, nutrition requirements and recommended intakes, in addition to public and clinical nutrition (Deslie,2012).

There exists a wide gap between needs and reality in the training of nutrition professionals in Africa. The recommended need for West Africa is set at $600 \mathrm{BSc}, 60 \mathrm{MSc}$ and $30 \mathrm{Ph} . \mathrm{D}$. nutrition professionals per 5 million people; however, the 2010 estimation was at 120, 140, and 14 respectively (Pepping, 2010; Brown et al., 2010). There is also the issue of quality, as training needs to be relevant, connected with policy, programmes, and research, and competency-based. Most of the teaching is now predominantly theoretical (Delisle et al., 2017). Furthermore, the expertise of nutrition professionals in many African countries is limited to assessment and management malnutrition (Delisle, 2012) and these skills and competences are grossly inadequate in meeting the human resource demands for an appropriate response to the high burden of malnutrition in the continent. It is therefore absolutely urgent to improve the professional training of nutritionists at all and appropriate levels of the health system.

In Nigeria, over one-third of under-5 children were stunted both in 2013 and 2018. In 2018, only $29 \%$ of children under 6 months were currently being exclusively breastfed; and only $11 \%$ of children age 6-23 months were fed a minimum acceptable diet. Overweight and obesity among women of reproductive age increased from $25 \%$ in 2013 to $28 \%$ in 2018 (NPC and ICF, 2014; 2019). More than half (56\%) of women had minimum dietary diversity, while more than twothirds (68\%) of children age 6-59 months and 58\% of women age 15-49 were anaemic (NPC and ICF, 2019). To address this nutritional situation, it is necessary for nutritionists to work as active professionals, particularly in the country's health sector.

According to Africa Public Health Alliance, Nigeria was reported to have about $25 \%$ of the physicians the country needs, $45 \%$ of nurses and midwives, and $12 \%$ of the needed pharmacists but the need for nutrition professionals in the country's health sector was ignored (WHO, 2012; Delisle, 2012). Even with the current low level of engagement, nutrition graduates are often seen to have career engagement in several non-nutrition and non-health sectors often due to lack of practical skills and competences as well as lack of experience (Leshi and Omobitan; 2019). It is thus essential to explore the work readiness of the current pool of university-trained students who will hopefully engage in career advancement in the field of human nutrition and dietetics in Nigeria.

\section{METHODOLOGY}

This descriptive cross-sectional study was conducted among final year undergraduate and postgraduate students from universities offering Nutrition and Dietetics programmes in Nigeria. All data were collected through an online version of a semi-structured self-administered questionnaire in English. The questionnaire was piloted among students in the Department of Human Nutrition and Dietetics, the University of Ibadan for content validity and consistency with the objective of the study before onward distribution to the study participants; however, no factor validity or reliability testing was done due to the open-ended nature of most of the questions in the questionnaire and the information intended for it to elicit. The questionnaire was inputted on the Google form platform and the link to the survey was shared with eligible students. Data collection took place from January to May 2019. Data obtained included background information of the students, the exact programme of study and degree in view, experiences and challenges in their 
current academic programme, willingness and readiness to pursue and engage in nutrition and dietetics related jobs, as well as their perception of their own skills and competences for future career and work engagements. Data were analysed using the IBM SPSS version 20.0.

\section{RESULTS}

A total of 109 students from twelve universities across Nigeria completely responded to the questionnaire. Most respondents were female (73\%). The average age of the students was 23.8 years with a majority $(63 \%)$ within the age bracket of 21 and 25 years. About half of the respondents $(49 \%)$ attended universities in the southwestern region of the country and 7 out of every ten of respondents were in their final year of a bachelor's programme in nutrition and dietetics. Most (90\%) of the undergraduate students indicated that their enrolment was a choice based on personal interest; $9 \%$ indicated that it was because they were left with no other choice of courses while only $1 \%$ based their enrolment on the influence of their parents and guardians.

Table 2 provides information on the perceptions of the graduate trainees in the field of nutrition and dietetics on their training programme and their work preparedness. Almost all (96\%) reported that they were enjoying their current training programme. Most $(96 \%)$ indicated their willingness to specialize in the field of nutrition, while $82.6 \%$ were willing to pursue their work engagement and specialize in the field of dietetics.

Two-thirds of the trainees recognized that they were eligible for any work engagement in the field of nutrition and dietetics, but only half of the trainees felt they were ready to start work. Table 3 provides details on the perceived barriers to readiness for career engagement. The two main barriers to effective training were inadequate infrastructure and little practical experience in the course of their training programme. Also shown in Table 3 are the reasons for non- willingness to work in the field of nutrition and/or dietetics upon graduation, including no sign of a guaranteed job upon graduation from the university, lack of effective national professional regulation of dietetics programmes in Nigeria, as well as difficulties to be registered and to practice as a dietician at any region of the country. The respondents' reasons for their non-readiness to work in the field of nutrition and/or dietetics upon graduation were insufficient practical and hands-on experience, lack of most of the soft skills required to work, loss of passion, and poor exposure to opportunities and possibilities for graduates in the field. The three main explanations for their non-eligibility for their desired job were inadequacy of soft skills, lack of work experience, and lack of pre-requisite qualifications as indicated in most job advertisements.

Figure 1 presents the common areas of interest as reported by the respondents. Six out of every ten trainees were interested in clinical nutrition and diet therapy while $43 \%$ were interested in community and public health nutrition. Other areas of interest as reported by the respondents are; sports nutrition, nutritional policy, and advocacy, maternal and child nutrition, industry, research and academia as well as food composition and analysis. The main areas of interest are clinical nutrition $\&$ diet therapy and community \& public health nutrition. 
Table 1: Demographic and Academic Backgrounds of the Respondents

\begin{tabular}{|c|c|c|}
\hline Variable & Frequency & Percentage \\
\hline \multicolumn{3}{|l|}{ Gender } \\
\hline Male & 29 & 26.6 \\
\hline Female & 80 & 73.4 \\
\hline \multicolumn{3}{|l|}{ Age (years) } \\
\hline Below 21 & 15 & 13.8 \\
\hline $21-25$ & 68 & 62.4 \\
\hline $26-30$ & 22 & 20.2 \\
\hline Above 30 & 4 & 3.6 \\
\hline \multicolumn{3}{|l|}{ Mean $( \pm$ SD) $23.8 \pm 3.4$} \\
\hline \multicolumn{3}{|l|}{ Region of University } \\
\hline South-West & 53 & 48.6 \\
\hline South-East & 32 & 29.4 \\
\hline South-South & 16 & 14.7 \\
\hline North & 8 & 7.3 \\
\hline \multicolumn{3}{|l|}{ Programme } \\
\hline Postgraduate & 33 & 30.3 \\
\hline Undergraduate & 76 & 69.7 \\
\hline \multicolumn{3}{|l|}{$\begin{array}{l}\text { Reason of enrolment for postgraduate programme } \\
(n=33)\end{array}$} \\
\hline Acquisition of in-depth/further knowledge of nutrition & 20 & 60.6 \\
\hline $\begin{array}{l}\text { Enhance career profile for competitive advantage in job } \\
\text { pursuit }\end{array}$ & 13 & 39.4 \\
\hline \multicolumn{3}{|l|}{$\begin{array}{l}\text { Reason of enrolment for undergraduate programme } \\
(n=76)\end{array}$} \\
\hline Personal interest/choice & 68 & 89.5 \\
\hline Had no other option & 7 & 9.2 \\
\hline Parents'/Guardians' choice & 1 & 1.3 \\
\hline Total & 109 & 100.0 \\
\hline
\end{tabular}

Information on the skills and competences related to envisaged career engagement provided by their current training programme compared to those they desired are presented in Table 4 . Those provided include communication skills, leadership and teamwork, counselling skills, project management, technical skills/knowledge of nutrition, and the use of statistical and nutritional software. The desired skills and competences include communication skills, leadership, and teamwork, clinical and practical exposure, research, and project management skills. It is noteworthy that half of the respondents did not know skills and competences desired by employers. Critical thinking and problem-solving skills, communication skills, technical/practical knowledge of nutrition, and research and project management skills were listed by respondents.

\section{DISCUSSION}

This study described the willingness and readiness of trainees of Nutrition and Dietetics in Nigerian universities to pursue a career in these fields as well as perceived barriers to the 
Table 2: Perceptions of training programme and work preparedness

\begin{tabular}{lll}
\hline Variable & Frequency & Percentage \\
\hline $\begin{array}{l}\text { Enjoyment of the training programme } \\
\text { Yes }\end{array}$ & 105 & 96.3 \\
No & 4 & 3.7 \\
$\begin{array}{l}\text { Willingness to work in the field of nutrition upon } \\
\text { graduation }\end{array}$ & \\
Yes & 103 & 94.5 \\
No & 6 & 5.5 \\
Willingness to work in the field of dietetics upon & & \\
graduation & 90 & 82.6 \\
Yes & 19 & 17.4 \\
No & & \\
Readiness to work in the field of nutrition and/or & & \\
dietetics & 90 & 82.6 \\
Yes & 19 & 17.4 \\
No & & \\
Perceived current work eligibility & 72 & 66.1 \\
Yes & 37 & 33.9 \\
No & & \\
General perception on readiness to work & 1 & 0.9 \\
Not interested & 16 & 14.7 \\
Not ready & 37 & 33.9 \\
$\begin{array}{l}\text { Barely ready } \\
\text { Ready }\end{array}$ & 55 & 50.5 \\
\hline
\end{tabular}

attainment of their careers. Findings from this study are similar to previous studies in the United States of America where almost all undergraduate students chose to study Nutrition and Dietetics undergraduate students, found out that parental influence and academic performance in secondary school were the major factors that influenced students' choice of career. These factors were considered above personal interest. In the present study, personal choice and interest of the respondents to study nutrition and dietetics could be attributed to the attention being given to nutrition in recent times as well as priority on nutrition in some of the global and national agendas.

A large percentage of our respondents reported that they were enjoying their current training programme and were willing to work in the field of Nutrition and Dietetics. This could be because the majority made their choice to study the programme either at the undergraduate level or postgraduate level and were not influenced or pressured by any external force in making their career choice. Interest has been described as a powerful motivational process that energizes learning, guides academic and career trajectories, and is essential to academic success (Harackiewicz, Smith, Priniski, 2016). The reasons provided by those who indicated not to have enjoyed the training programme pointed to the need for a review of the minimum training standard as provided by the National University Commission as well as the call for the government to revitalize the university by the provision of basic infrastructure and cutting-edge 
Table 3: Perceived Barriers to Willingness for Career-Leap in Nutrition and Dietetics

\begin{tabular}{|c|c|c|c|}
\hline $\begin{array}{l}\text { Barriers to the } \\
\text { training programme }\end{array}$ & $\begin{array}{l}\text { Reason for non- } \\
\text { willingness to work in } \\
\text { the field of } \\
\text { Nutrition/dietetics } \\
\text { upon graduation }\end{array}$ & $\begin{array}{l}\text { Reasons for non- } \\
\text { readiness to work in } \\
\text { the field of } \\
\text { Nutrition/Dietetics } \\
\text { upon graduation }\end{array}$ & $\begin{array}{l}\text { Explanations for } \\
\text { non-eligibility for } \\
\text { the desired Job }\end{array}$ \\
\hline $\begin{array}{l}\text { Too many theories and } \\
\text { less practical experience } \\
\text { in the training } \\
\text { programme. }\end{array}$ & $\begin{array}{l}\text { No guaranteed job upon } \\
\text { graduation from school, } \\
\text { especially for those who } \\
\text { want to specialize as } \\
\text { dieticians. }\end{array}$ & $\begin{array}{l}\text { Lack of practical and } \\
\text { hands-on experience } \\
\text { and required soft } \\
\text { skills. }\end{array}$ & $\begin{array}{l}\text { Inadequate soft } \\
\text { skills. }\end{array}$ \\
\hline \multirow[t]{2}{*}{$\begin{array}{l}\text { Inadequate } \\
\text { infrastructure for the } \\
\text { training programme. }\end{array}$} & $\begin{array}{l}\text { Lack of professional } \\
\text { regulation of the } \\
\text { dietetics profession in } \\
\text { Nigeria. }\end{array}$ & $\begin{array}{l}\text { Lack of interest in the } \\
\text { practice at hospital } \\
\text { setting. }\end{array}$ & $\begin{array}{l}\text { Lack of work } \\
\text { experience. }\end{array}$ \\
\hline & $\begin{array}{l}\text { Difficulty in becoming a } \\
\text { Registered Dietician in } \\
\text { Nigeria. }\end{array}$ & $\begin{array}{l}\text { Poor exposure to } \\
\text { opportunities and } \\
\text { possibilities as } \\
\text { graduates. }\end{array}$ & $\begin{array}{l}\text { Lack of Requisite } \\
\text { qualifications. }\end{array}$ \\
\hline
\end{tabular}

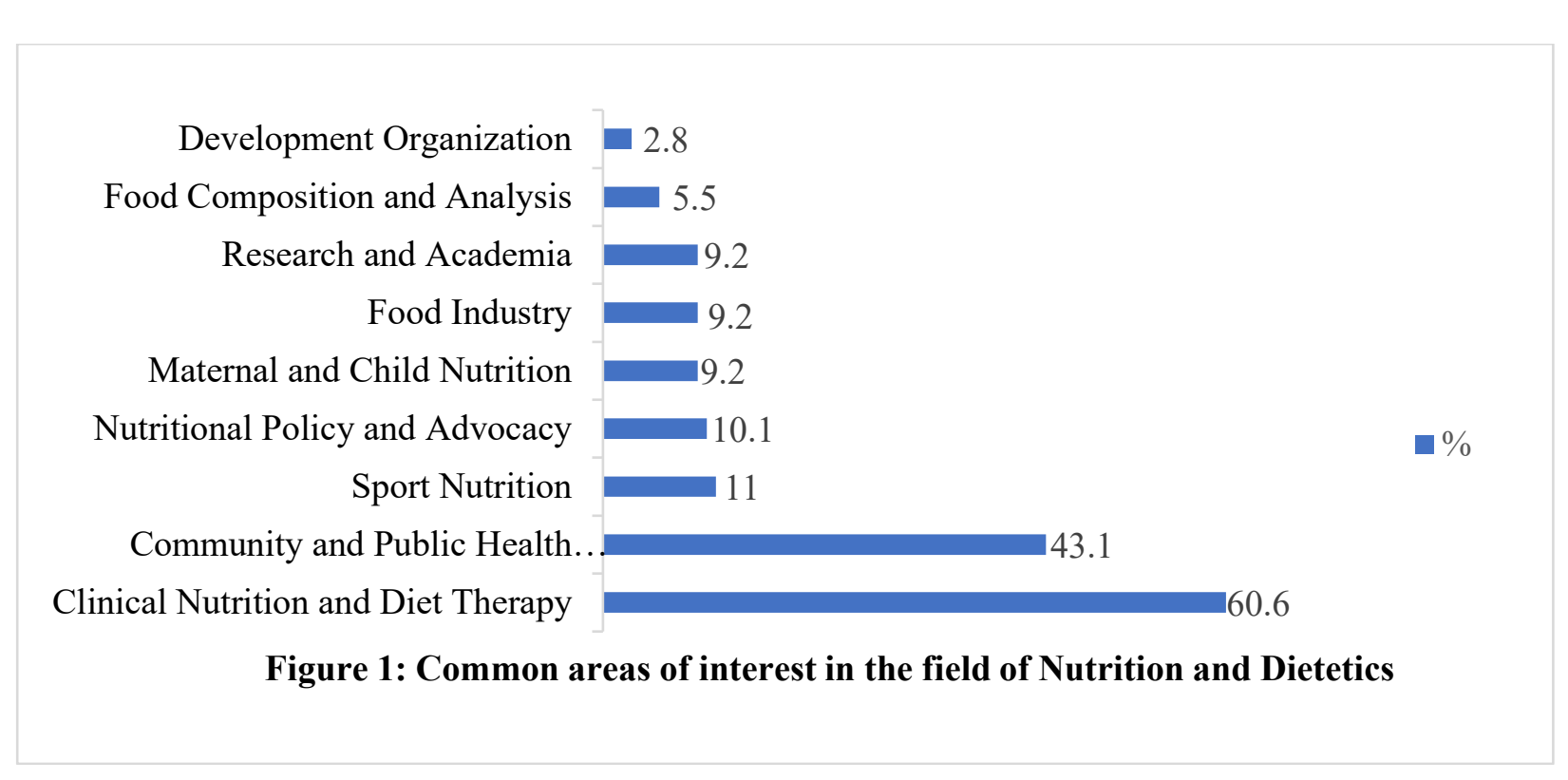

training facilities. A similar study among dental students in Nigeria also reported poor infrastructure and poor electricity as some of the factors adversely affecting the quality of clinical training they were receiving (Isiekwe et al., 2016). In an assessment of Human Nutrition training in West Africa, Sodjinou and colleagues (2014) reported that in nearly all of the nutrition training programmes, there was a need to refocus the teaching format from predominantly theory-based to be more practical-based and this can better be achieved through the review of the basic minimum training standard in the country. Students may not have been 
Table 4: Career-Related Skills and Competences of the Nutrition and Dietetic Trainees

\begin{tabular}{lcc}
\hline Variable & Frequency & Percentage \\
\hline $\begin{array}{l}\text { Available skills and competences from the current training } \\
\text { programme relevant to envisaged career engagement }\end{array}$ & \\
Communication skills & 39 & 35.8 \\
Leadership and teamwork & 29 & 26.6 \\
Counselling skills & 27 & 24.8 \\
Project management & 21 & 19.3 \\
Technical skills/ nutritional knowledge & 19 & 17.4 \\
Statistical/nutritional software & 21 & 19.3 \\
Desired skills and competences from the current training & & \\
programme & & \\
Communication skills & 6 & 5.5 \\
Leadership and teamwork & 11 & 10.1 \\
Clinical/practical exposure & 52 & 47.7 \\
Research and project management skills & 23 & 21.1 \\
No specific skill and competence desired & 30 \\
Trainees perceived skills and competences as desired by & & 27.5 \\
employers & & \\
Don't know & & \\
Critical thinking and problem-solving skills & 54 & 49.5 \\
Communication skills & 14 & 12.8 \\
Technical/practical knowledge of Nutrition & 19 & 17.4 \\
Research and project management skills & 21 & 19.3 \\
\hline
\end{tabular}

adequately equipped to address the prevailing nutrition problems in the region; hence the need to urgently prioritize the structure and format of the training programmes.

As the field of Nutrition and Dietetics is known to constantly evolve, it is essential to ensure that trainees are taught and exposed in line with current as well as emerging issues in the field globally, regionally, and nationally. The willingness of the nutrition and dietetics trainees in Nigeria to work in their fields was high; however, this did not measure up to their perceived work eligibility and particularly readiness to work. The explanation for the inadequacy of soft skills thought to be required for their desired jobs further affirms the findings of Sodjinou and colleagues (2014). Even if the students are exposed to a form of soft skills, when not put to use through practical experience and demonstration, self-confidence on the utilization of such skills may not be attained. Another justification for non-eligibility and non-readiness for work as identified in this study is lack of work experience and pre-requisite qualifications, especially in the field of dietetics where only a few of the trainees have the opportunity to engage in the competitive internship programme after graduation from the university. In addition, many of the respondents in this study were undergraduates in their final year with limited or no work experience. This, however, indicates the importance of volunteering for students which is capable of exposing the students and enabling them to utilize their technical and soft skills. Volunteering also serves as the basis for gathering experience in readiness for paid employment. 
This study revealed that the majority of the trainees were interested in the field of clinical nutrition and diet therapy as well as community and public health nutrition. This is similar to previous findings by Hughes and Desbrow (2005) who attributed students' interest to their narrow views on the opportunities and diversity of practice that are present in the field of Nutrition and Dietetic. Some respondents in the current study reported poor exposure to opportunities and possibilities as Nutritionists or Dietitians as a key barrier to pursuing a career in these fields.

Nigeria has one of the highest burdens of malnutrition globally and this had led to a lot of nutritionspecific and nutrition-sensitive interventions and programmes. The number of nutrition-related projects in Nigeria has increased as many development partners have prioritized nutrition. Some of the reasons stated for non-willingness and readiness to pick up a career in the field of nutrition and dietetics include "no guaranteed job," "lack of professional regulation of the dietetics profession," and "difficulty in becoming a registered Dietitian in Nigeria." The lack of a guaranteed job as a barrier that has also been reported in other career paths in Nigeria. Although the unemployment rate is on the rise in most of the developing countries (Okojide, Adekeye, Bakare, 2018), previous studies have identified widespread job unavailability among university graduates (Emeh, Nwanguma, Abaroh, 2012; Pitan, 2015).

However, Emeh and colleagues (2012) showed that the high rate of unemployment of the university graduates in Nigeria was not only due to the unavailability of jobs, but also because there are few eligible candidates with sufficient employable skills as required by the employers. Beyond the desire or interest in a career path, skills and competence are another factor required for any work placement or career engagement (Emeh, Nwanguma, Abaroh, 2012). Lack of the required skills or competence can hinder individuals trained and knowledgeable about a field from getting their desired job. According to Deslie (2017), when nutrition professionals are unavailable for field programmes or lack required skills and competences, international nongovernmental organizations and development partners often engage non-nutrition professionals.

Our results reveal a gap in skills and competences provided by the nutrition training programmes in the country. Another interesting observation was the high rate of ignorance on desired skills and competencies by employers. This suggests that nutrition and dietetics trainees will not know the skills to look out for and develop in order to be more suitable for employment after graduation. Fanzo and colleagues (2015) reported some of the skills a nutritionist should possess in this era to address emerging nutrition challenges, and these skills were broadly classified into technical/hard skills and soft skills. Technical skills referred to skills related to basic nutrition science, public health nutrition, food environment, and quantitative analysis while soft skills include skills in communication, advocacy, management, team building, and leadership, among others. This is similar to the required competencies reported by nutrition professionals in Africa, which also included critical thinking and problem-solving skills (Brown et al., 2010). A possible solution to filling the skills and competence gap is to review the nutrition curricula used in Nigerian universities and to then tailor them to addressing the expressed needs of employers, as well as the nutritional problems as they currently exist in the country.

In conclusion, this study revealed that the most of the Nutrition and Dietetics trainees in Nigerian universities were willing and ready to start a career in the field but only a few were aware of the desired skills and competences for work engagement. There also seems to be a gap between the desired skills and competences and what is being provided in the training programmes thus a reduced likelihood that many trainees may have career engagement in the field of Nutrition and 
Dietetics, which leads to losing many trainees to other fields or professions. A reorientation of the skills and competencies provided in university curricula is called for, including the inclusion of more relevant practical and hands-on experiences for Nutrition and Dietetics students.

\section{REFERENCES}

Brown KH, McLachlan M, Cardosa P, Tchibindat F, Baker SK (2010). Strengthening public health nutrition research and training capacities in West Africa: Report of a planning workshop convened in Dakar, Senegal, 26-28 March 2009. Glob Public Health, 5(Suppl):S1-19.

Delisle H (2012). Empowering our profession in Africa [Commentary]. World Nutrition, 3(6):269-284

Delisle H, Shrimpton R, Blaney S, Du Plessis L, Atwood S, Sanders D, \& Margetts B (2017). Capacity-building for a strong public health nutrition workforce in low resource countries. Bull World Health Organ, 95:385-388

Emeh IE, Nwanguma EO, Abaroh JJ (2012). Engaging youth unemployment in Nigeria with youth development and empowerment programmes: The Lagos state in focus. Interdisciplinary Journal of Contemporary Research in Business, 4:1125-1141.

Fanzo JC, Graziose MM, Kraemer K, et al. (2015). Educating and training a workforce for nutrition in a post-2015 world. Adv Nutr, 6(6):639-647.

Felton TM, Nickols-Richardson SM, Serrano E, Hosig KW (2008). African-American students' perceptions of their majors, future professions, and the dietetics major and profession: a qualitative analysis. Journal of the American Dietetic Association, 108(7):1192-1197.

Food and Agriculture Organization, World Health Organization (2016). United Nations decade of action on nutrition: towards country-specific smart commitments for action on nutrition. http://www.fao.org/3/a-i6130e.pdf

Frenk J, Chen L, Bhutta ZA, et al. (2010). Health professionals for a new century: transforming education to strengthen health systems in an interdependent world. TheLancet, 376:1923-1958

Harackiewicz J M, Smith J L, Priniski SJ (2016). Interest Matters: The Importance of Promoting Interest in Education. Policy Insights from the Behavioral and Brain Sciences, 3(2):220-227.

Hughes R, Desbrow B (2005). Aspiring dietitians study: A pre-enrolment study of students' motivations, awareness and expectations relating to careers in nutrition and dietetics. Nutrition \& Dietetics, 62(2-3):106-109

Isiekwe GI, Umeizudike KA, Abah AA, Fadeju AD (2016). Undergraduate dental education in Nigeria: perceptions of dental students and recent dental graduates. Odontostomatol Trop, 39(154):15-23.

Kobel KA (1997). Influences on the selection of dietetics as a career. Journal of the American Dietetic Association, 97:254-257.

Leshi O.O. and Omobitan I (2019). Tracer study of Graduates in the Department of Human Nutrition, University of Ibadan. A BSc project submitted to the Department of Human Nutrition, University of Ibadan, Nigeria. Under the supervision of Dr O.O. Leshi.

National Population Commission (NPC) and ICF. (2019). Nigeria Demographic and Health Survey 2018 - Final Report. Abuja, Nigeria: NPC and ICF. http://dhsprogram.com/pubs/pdf/FR359/FR359.pdf 
National Population Commission (NPC) Nigeria and ICF International (2014). Nigeria Demographic and Health Survey 2013. Abuja, Nigeria: NPC/Nigeria and ICF International. http://dhsprogram.com/pubs/pdf/FR293/FR293.pdf

Okojide A, Adekeye A, Bakare E (2018). Factors influencing career choice among undergraduates in covenant university, Nigeria. Proceedings of ICERI 2018 Conference: pp. 2246-2252.

Pepping F (2010). The current capacity for training in public health nutrition in West Africa. Global Public Health, 5(S1):20-41

Pitan OS (2015). An assessment of generic skills demand in five sectors of the Nigerian labor market. Public and Municipal Finance, 4(1):28-36.

Popkin BM, Corvalan C, Grummer-Strawn LM (2020). Dynamics of the double burden of malnutrition and the changing nutrition reality. The Lancet, 395: 65-74.

Sodjinou R, Fanou N, Deart L, Tchibindat F, Baker S, Bosu W, Peppind F, Delisle H, and the regional nutrition working group (2014). Region-wide assessment of the capacity for human nutrition training in West Africa: current situation, challenges, and way forward. Glob Health Action, 7:23247.

Tang YT (2011). Understanding the Factors Influencing Career Decisions of Chinese Dietetic Students. Master of Science thesis, Department of Applied Human Nutrition, Mount Saint Vincent University.

Tzioumis E, Adair LS (2014). Childhood dual burden of under- and overnutrition in low- and middle-income countries: A critical review. Food and Nutrition Bulletin, 35(2): 230-43.

United Nations (2011). United Nations General Assembly: Political Declaration of the High Level Meeting of the General Assembly on the Prevention and Control of NonCommunicable Diseases. http://www.un.org/ga/search/view doc.asp?symbol=A/66/L.1

World Bank (2006). World Bank. Repositioning Nutrition as Central to Development. A Strategy for Large-Scale Action. World Bank: Washington DC. https://openknowledge.worldbank.org/handle/10986/7409

World Health Organization (2012). http://www.who.int/workforcealliance/media/news 12012/AfricanMinistersofEducation statement.pdf

World Health Organization (2013). Global nutrition policy review: what does it take to scale up nutrition action? Geneva: World Health Organization 